\title{
Crude Protein and Metabolizable Energy Levels for Layers Reared in Hot Climates
}

\section{-Author(s)}

Almeida $\mathrm{VR}^{(1)}$

Dias $A N^{(1)}$

Bueno CFD (1)

Couto FAP(l)

Rodrigues $P A^{(1)}$

Nogueira WCL ${ }^{(1)}$

Faria Filho DE ${ }^{\left(I^{*}\right)}$

\section{Mail Adress}

(I) Universidade Federal de Minas Gerais Instituto de Ciências Agrárias, Montes Claros, Minas Gerais, Brazil.

${ }^{\left({ }^{*}\right)}$ Author for correspondence: Av. Universitária, n. 1000 Bairro Universitário, Caixa postal 135 Montes Claros, MG, CEP 39404-547.

E-mail: fariafilho@ufmg.br

\section{-Keywords}

Thermal homeostasis, nutrition, environmental temperature, cloacal temperature.
Submitted: September/2010

Approved: May/2012

\section{ABSTRACT}

The objective of the present study was to evaluate the effects of different dietary crude protein (CP) and metabolizable energy (ME) levels on the performance, internal and external egg quality, and cloacal temperature of commercial layers reared in hot climate. In this trial, 100 commercial Hy-Line W-36 layers between 20 and 32 weeks of age were distributed according to a completely randomized experimental design with a $2 \times 2$ factorial arrangement, consisting of two CP levels (15 e $18 \%$ ) and two ME contents (2700 and $3100 \mathrm{kcal} / \mathrm{kg}$ ) with five replicates per treatment and 10 birds per replicate. Performance (feed intake, egg production, egg mass, and feed conversion ratio), internal (Haugh units and albumen and yolk percentage) and external (eggshell \% and thickness) egg quality parameters were evaluated. Cloacal temperature was measured in two birds per replicate at 8:00 $\mathrm{h}$ and 13:00 $\mathrm{h}$. The diet containing $2700 \mathrm{kcal} \mathrm{ME} / \mathrm{kg}$ promoted the best performance, whereas the worse performance observed in birds fed the diet with $3100 \mathrm{ME} /$ $\mathrm{kg}$ was partially recovered when the diet contained 18\% CP. Haugh units worsened as dietary CP level increased. The other external and internal egg quality parameters were not affected by dietary $\mathrm{CP}$ or ME levels. The cloacal temperature of birds fed 15\% CP was lower in the morning and higher in the afternoon relative to those fed $18 \% \mathrm{CP}$, which temperature did not change during the day. It was concluded that dietary CP and ME levels influenced the performance and the body temperature of commercial layers.

\section{INTRODUCTION}

Birds are homoeothermic animals, that is, they need to maintain their body temperature within a narrow range around $41^{\circ} \mathrm{C}$ (Furlan \& Macari, 2002), and therefore, rearing temperatures thermoneutral (Leeson et al., 2000). However, Brazil presents a predominantly tropical climate, with average temperatures usually above those recommended for commercial poultry production.

The main consequence of exposure to heat is that birds reduce their feed intake (Geraert et al., 1996) in order to diminish metabolic heat production in an attempt to maintain their body temperature (Koh \& Macleod, 1999); however, major reduction in energy and nutrient intake may compromise productivity (Leeson et al., 2000).

The heat increment produced by protein metabolism is higher than that of carbohydrates, which in turn is higher than that of fat (Pond et al., 2005). This is the reason why it is recommended increasing dietary energy levels by the inclusion of oil and reducing protein level under heat stress situations (Leeson et al., 2000).

Metabolizable energy requirements of commercial layers depend on environmental temperature (Rostagno et al., 2005; Sakomura et al. 2005); it increases when the environment is cold or hot (Sakomura 
et al., 2005). Therefore, under heat stress situations, increasing energy levels in the diet of commercial layers by the inclusion of oil may compensate the low feed intake and supply the higher energy requirements. Nevertheless, Usayran et al. (2001) did not find any relationship between environmental temperature and dietary oil levels fed to commercial layers.

Because protein presents the higher heat increment among nutrients (Pond et al., 2005), it is usually recommended to reduce dietary protein levels when poultry are reared in hot environments. Nevertheless, recent studies with broilers have shown that it is better to increase dietary CP level to compensate the low protein intake resulting from exposure to heat (Faria Filho, 2006). No studies on this matter were found with commercial layers in literature.

The objective of the present study was to evaluate the effects of different dietary $\mathrm{CP}$ and ME levels on the performance, internal and external egg quality, and cloacal temperature of commercial layers reared in hot climate.

\section{MATERIAL AND METHODS}

This study was carried out at the poultry house of the Institute of Agrarian Sciences of the Federal University of Minas Gerais, Montes Claros, MG, Brazil.

In total, 200 commercial Hy-Line W-36 layers between 20 and 32 weeks of age were distributed according to a completely randomized experimental design with a $2 \times 2$ factorial arrangement, consisting of two CP levels (15 e 18\%) and two ME contents $(2700$ and $3100 \mathrm{kcal} / \mathrm{kg})$. with five replicates per treatment and 10 birds per replicate. Feed and water were supplied ad libitum, and a lighting program of 17 hours of light per day was adopted. Birds were submitted to conventional commercial management. The experimental diets are shown in Table 1.

Minimal, maximal and average environmental temperature and relative humidity during the experimental period are presented in Table 2.

The following performance parameters were evaluated when layers were 20 to 32 weeks old: feed intake ( $\mathrm{g} / \mathrm{hen} /$ day), egg production (\%/hen/ day), egg weight (g), egg mass ( $g /$ hen/day), and feed conversion ratio $(\mathrm{g} / \mathrm{g})$. Egg production was daily recorded, and the results are expressed as a percentage of the number of hens housed. Egg weight was determined by weighing all the eggs produced per experimental unit on the last experimental day, as calculating the average. Egg mass was calculated by multiplying egg
Table 1 - Experimental diets.

\begin{tabular}{|c|c|c|c|c|}
\hline \multirow{2}{*}{ Ingredients } & \multicolumn{4}{|c|}{ Feeds } \\
\hline & \multicolumn{2}{|c|}{$2700 / 15$ 2700/18 } & $3100 / 15$ & $3100 / 18$ \\
\hline Corn & 64.9 & 59.9 & 60.4 & 50.3 \\
\hline Soybean meal & 18.5 & 26.0 & 19.5 & 27.8 \\
\hline Calcitic limestone & 8.1 & 8.1 & 8.1 & 8.1 \\
\hline Soybean oil & 0 & 0 & 6.0 & 7.8 \\
\hline Inert material (rice husks) & 2.5 & 0 & 0 & 0 \\
\hline Supplement* & 6.0 & 6.0 & 6.0 & 6.0 \\
\hline TOTAL & 100 & 100 & 100 & 100 \\
\hline \multicolumn{5}{|l|}{ Energy and nutrients } \\
\hline Metabolizable energy (kcal/kg) & 2700 & 2700 & 3100 & 3100 \\
\hline Crude protein (\%) & 15 & 18 & 15 & 18 \\
\hline Calcium (\%) & 3.8 & 3.8 & 3.8 & 3.8 \\
\hline \multicolumn{5}{|c|}{$\begin{array}{l}\text { * Vitamin, mineral, and additive supplement - Levels per } \mathrm{kg} \text { of feed } \\
\text { vitamin A } 8818 \mathrm{IU} \text {; vitamin D3 } 2800 \mathrm{IU} \text {; vitamin E } 5.01 \mathrm{mg} \text {; vitamin } \\
0.33 \mathrm{mg} \text {; thiamine } 4.41 \mathrm{mg} \text {; riboflavin } 1.14 \mathrm{mg} \text {; pyridoxine } 5.01 \mathrm{mg} \\
\text { cyanocobalamin } 12.42 \mathrm{mcg} \text {; folic acid } 0.20 \mathrm{mg} \text {; pantothenic acid } 7.01 \mathrm{mg} \\
\text { niacin } 22.02 \mathrm{mg} \text {; choline } 280.02 \mathrm{mg} \text {; antioxidant } 324 \mathrm{mg} \text {; copper } 16.2 \\
\mathrm{mg} \text {; iodine } 1.68 \mathrm{mg} \text {; selenium } 0.29 \mathrm{mg} \text {; zinc } 71.93 \mathrm{mg} \text {; iron } 40.5 \mathrm{mg} \\
\text { cobalt } 0.16 \mathrm{mg} \text {; manganese } 84.24 \mathrm{mg} \text {; calcium } 6 \mathrm{~g} \text {; phosphorus } 3.3 \mathrm{~g} \\
\text { sodium } 0.96 \mathrm{~g} \text {; methionine } 0.72 \mathrm{~g} \text {; crude protein } 17 \% \text { of the supplement } \\
\text { metabolizable energy } 1000 \mathrm{kcal} / \mathrm{kg} \text { supplement. }\end{array}$} \\
\hline
\end{tabular}

production by egg weight. Feed conversion ratio was obtained by dividing feed intake by egg mass.

On the last day of the experiment, internal egg quality was evaluated relative to Haugh units and yolk and albumen percentages. Haugh units (HU) were determined according to the equation of Nesheim et al. (1979): $\mathrm{HU}=100 \times \log \left(h+7.57-1.7 p^{0.37}\right)$, where $h$ is albumen height $(\mathrm{mm})$ and $p$ is egg weight $(\mathrm{g})$. Albumen height was measured at $1 \mathrm{~cm}$ of the yolk, using a 0.1 $\mathrm{mm}$ precision pachymeter. Eggs were weight in a 0.01 -

Table 2 - Environmental temperature and air relative humidity during the experimental period.

\begin{tabular}{ccccccc}
\hline \multirow{2}{*}{ Week of age } & \multicolumn{2}{c}{ Environmental temperature $\left({ }^{\circ} \mathrm{C}\right)$} & \multicolumn{3}{c}{ Air relative humidity (\%) } \\
& Minimal & Maximal & Average & Minimal & Maximal & Average \\
\hline 20 & 22.1 & 32.6 & 27.4 & 43 & 90 & 67 \\
21 & 21.4 & 30.3 & 25.9 & 40 & 92 & 66 \\
22 & 21.9 & 30.3 & 26.1 & 38 & 88 & 63 \\
23 & 19.0 & 29.5 & 24.3 & 50 & 87 & 69 \\
24 & 19.6 & 31.3 & 25.4 & 48 & 92 & 70 \\
25 & 20.7 & 32.0 & 26.4 & 49 & 85 & 67 \\
26 & 20.0 & 29.0 & 24.5 & 40 & 88 & 64 \\
27 & 18.9 & 29.8 & 24.4 & 48 & 85 & 67 \\
\hline 28 & 20.7 & 30.6 & 25.7 & 45 & 84 & 65 \\
29 & 22.0 & 30.6 & 26.3 & 48 & 88 & 68 \\
\hline 30 & 20.0 & 29.3 & 24.7 & 59 & 92 & 76 \\
31 & 21.9 & 30.6 & 26.3 & 62 & 86 & 74 \\
\hline 32 & 21.0 & 32.3 & 26.7 & 54 & 90 & 72 \\
\hline Average & 20.7 & 30.6 & 25.7 & 48 & 88 & 68 \\
\hline
\end{tabular}




\begin{tabular}{|c|c|c|c|c|c|}
\hline Factors & $\mathrm{FI}$ & PRO & EW & EM & FCR \\
\hline \multicolumn{6}{|l|}{ Metabolizable energy (kcal/kg) } \\
\hline 2700 & 108.8 & 88.7 & 56.6 & 50.7 & $2.21 \mathrm{~b}$ \\
\hline 3100 & 90.4 & 79.3 & 55.8 & 44.2 & $2.07 \mathrm{a}$ \\
\hline \multicolumn{6}{|l|}{ Crude protein (\%) } \\
\hline 15 & 96.8 & 81.1 & $54.9 \mathrm{~b}$ & 44.8 & $2.23 b$ \\
\hline 18 & 102.4 & 86.9 & $57.6 \mathrm{a}$ & 50.1 & $2.04 \mathrm{a}$ \\
\hline \multicolumn{6}{|l|}{ Analysis of variance } \\
\hline Metabolizable energy (ME) & 0.000 & 0.000 & 0.119 & 0.000 & 0.010 \\
\hline Crude protein (CP) & 0.021 & 0.001 & 0.000 & 0.000 & 0.002 \\
\hline ME $\times$ CP interaction & 0.016 & 0.018 & 0.128 & 0.004 & 0.28 \\
\hline CV (\%) & 4.73 & 3.57 & 2.00 & 3.26 & 4.84 \\
\hline
\end{tabular}

Means followed by different letter in the same column, within each factor, are different by the $\mathrm{F}$ test.

g precision scale. Yolk and albumen percentages; yolk and albumen were manually separated and weighed in a $0.01-\mathrm{g}$ precision scale and were expressed as percentages relative to fresh egg weight.

Eggshell quality was determined on the last experimental day in terms of eggshell thickness $(\mathrm{mm})$ and percentage (\% relative to fresh egg weight). Eggshells were first dried for 72 hours at room temperature, and then their thickness was measured using a $0.01-\mathrm{mm}$ precision pachymeter. Eggshell weight was determined in a $0.01-\mathrm{g}$ precision scale.

Cloacal temperature was measured in two hens per replicate by inserting a $0.1^{\circ} \mathrm{C}$ precision digital thermometer in the cloaca. This procedure was repeated for three consecutive days in the morning (starting at 8:00) and in the afternoon (starting at 13:00). During the morning, average environmental temperature was $21.8^{\circ} \mathrm{C}$ and average air relative humidity was $90 \%$, whereas in the afternoon, average environmental temperature was $31.4^{\circ} \mathrm{C}$ and average air relative humidity was $48 \%$.

Cloacal temperature data were analyzed according to a completely randomized experimental design with a $2 \times 2 \times 2$ factorial arrangement, which factor were dietary CP levels (15 or $18 \%$ ), dietary ME levels (2700 or $3100 \mathrm{kcal} / \mathrm{kg}$ ), and period (morning or afternoon), with two replicates of five hens each.

Data were checked for the presence of outliers, normality of studentized residuals (Cramer-Von-Misses test), and variance homogeneity (Brown Forsite test). When the assumptions of the model were accepted, data were submitted to analysis of variance and results were considered significant at $p<0.05$. The analyses were performed using SAS ${ }^{\circledR}$ (Statistical Analysis System), according to the procedures described by Littell et al. (2002).

\section{RESULTS AND DISCUSSION}

The recorded maximal and minimal temperatures were 30.6 and $20.7^{\circ} \mathrm{C}$, respectively (Table 2 ). It must be mentioned that the maximal temperature is above that considered optimal. During the afternoon of all experimental days, maximal temperature was higher than the thermoneutral temperature, and hens' behavior indicated they were suffering heat stress. Hens panted, moved very little and remained sitting, with the wings spread away from the body, which, according to Furlan \& Macari (2002), is a typical behavior of heat-stressed birds. On the other hand, the average and minimal temperatures recorded during the experiment were within the thermoneutral range for commercial layers, which, according to Leeson et al. (2000) is between 19 and $27^{\circ} \mathrm{C}$.

There was no significant interaction between $\mathrm{CP}$ and ME for egg weight and feed conversion ratio (Table 3). The diets containing $18 \%$ CP increased egg weight, as expected, because protein is an important component of eggs (Leeson et al., 2000), and higher CP contents determine higher $\mathrm{CP}$ deposition in the egg. These results agree with the findings of Pinto et al. (2002) with Japanese quails, who observed a positive linear 
Table 4 - Interaction between dietary metabolizable energy and crude protein for feed intake, egg mass, and egg production of commercial layers reared in hot climate.

\begin{tabular}{|c|c|c|}
\hline \multirow{2}{*}{ Crude protein (\%) } & \multicolumn{2}{|c|}{ Metabolizable energy (kcal/kg) } \\
\hline & 2700 & 3100 \\
\hline \multicolumn{3}{|c|}{ Feed intake (g/hen/day) } \\
\hline 15 & $108.94 \mathrm{aA}$ & $84.69 \mathrm{bB}$ \\
\hline 18 & $108.64 \mathrm{aA}$ & $96.16 \mathrm{ab}$ \\
\hline \multicolumn{3}{|l|}{ Egg production (\%) } \\
\hline 15 & $87.64 \mathrm{Aa}$ & $74.51 \mathrm{bB}$ \\
\hline 18 & $89.80 \mathrm{aA}$ & $84.08 \mathrm{ab}$ \\
\hline \multicolumn{3}{|c|}{ Egg mass (g/hen/day) } \\
\hline 15 & $49.33 \mathrm{bA}$ & $40.35 \mathrm{bB}$ \\
\hline 18 & $52.05 \mathrm{Aa}$ & $48.07 \mathrm{ab}$ \\
\hline
\end{tabular}

effect of $\mathrm{CP}(16,18,20,22$, and 24\%) on egg weight. ME levels did not influence egg weight, as previously reported by Costa et al. (2009).

Relative to feed conversion ratio, the highest CP and ME levels generated the best results. This may have been a consequence of the reduction in feed intake (Table 4). In addition, egg mass was higher when the diet contained 18\% CP compared with $15 \%$, independently of dietary ME content (Table 4). The lower feed intake, together with the higher egg mass, promoted better feed conversion ratio.

Feed intake, egg production, and egg mass were affected by the interaction between ME and CP levels (Table 4). The hens fed $3100 \mathrm{kcal} \mathrm{ME} / \mathrm{kg}$ presented lower feed intake, egg production, and egg mass relative to those fed $2700 \mathrm{kcal} \mathrm{ME} / \mathrm{kg}$; however, this effect was less pronounced in the birds fed $18 \%$ CP.

The hens fed the diet with high ME content presented lower feed intake, in agreement with Moraes et al. (1991) and Harms et al. (2000). This response may be explained by the fact that birds regulate their intake according to dietary energy level (Bertechini, 2006). However, when the diet contained $18 \% \mathrm{CP}$ and $3100 \mathrm{kcal} \mathrm{ME} / \mathrm{kg}$, the reduction in feed intake was not pronounced, probably because, due to the higher dietary protein content, energy requirement increased. Another explanation for the lower feed intake of the hens fed $3100 \mathrm{kcal} \mathrm{ME} / \mathrm{kg}$ was the high oil content of the feeds. Under these situations, feed passage from the gizzard to the duodenum is slower because the fat digestion in the duodenum is slow (Mateos \& Sell, 1981; Mateos et al., 1982; Andreotti et al., 2004) because fats need to be emulsified, thereby reducing the appetite.

The obtained lower egg production when highenergy diets were fed is consistent with the finding of Rosa et al. (1996), who observed higher egg production when layers were fed $2800 \mathrm{kcal}$ ME/kg compared with those fed $3100 \mathrm{kcal} \mathrm{ME} / \mathrm{kg}$. This may have been due to the lower feed intake of the hen fed the diet with $3100 \mathrm{kcal} \mathrm{ME} / \mathrm{kg}$ and $15 \% \mathrm{CP}$, and the resulting lower energy intake reduced egg production.

This may also explain the lower egg mass observed in those birds. This effect was not as pronounced in the layers fed $18 \% \mathrm{CP}$, who presented higher egg weight compared with those fed 15\% CP. Rabello et al. (2007) observed that low dietary protein level reduced albumen percentage, which may reduce egg weight, and consequently, egg mass.

There was no significant interaction of the tested factors for the evaluated internal and external egg quality parameters (Table 5). The eggs of layers fed $18 \%$ CP presented lower Haugh unit values than those fed $15 \%$ CP. This may be a result of the higher egg weight obtained for the birds fed $18 \% \mathrm{CP}$, which is used to calculate Haugh units. Dietary ME levels did not influence Haugh units. Yolk, albumen, and eggshell percentages and eggshell thickness were not affected by dietary ME or CP levels. Pavan et al. (2005) also did not observe any effect of CP levels $(18,20$, or $22 \%$ ) on the egg quality of layers.

Table 5 - Effect of dietary metabolizable energy and crude protein levels on yolk percentage (YO, \%), albumen percentage $(A L ; \%)$, eggshell percentage (ES; \%), Haugh units $(\mathrm{HU})$, and eggshell thickness (ET, mm) of commercial layers reared in hot climate.

\begin{tabular}{lccccc}
\hline Factors & YO) & AL & ES & HU & ET \\
\hline Metabolizable energy (kcal/kg) & & & & & \\
2700 & 26.0 & 57.72 & 15.5 & 86.9 & 0.32 \\
3100 & 26.3 & 57.10 & 16.4 & 85.6 & 0.32 \\
\hline Crude protein (\%) & & & & & \\
15 & 26.0 & 57.21 & 16.1 & 87.5 a & 0.32 \\
18 & 26.4 & 57.61 & 15.8 & $85.1 \mathrm{~b}$ & 0.32 \\
\hline Analysis of variance & & & & & \\
Metabolizable energy (ME) & 0.204 & 0.130 & 0.227 & 0.199 & 0.193 \\
Crude protein (CP) & 0.188 & 0.316 & 0.310 & 0.025 & 0.859 \\
ME x CP interaction & 0.569 & 0.540 & 0.115 & 0.074 & 0.723 \\
\hline CV (\%) & 2.47 & 1.41 & 4.36 & 2.47 & 1.63 \\
\hline $\begin{array}{l}\text { Means followed by different letters in the same column, within each } \\
\text { factor, are different by the F test (95\%). }\end{array}$ \\
\hline
\end{tabular}


There was a significant interaction between $C P$ levels and period of the day on cloacal temperature (Tables 6 and 7). The layers fed 18\% CP presented higher cloacal temperature than those fed 15\% CP only in the morning. Independently of dietary CP level, cloacal temperature was higher in the afternoon. ME levels did not affect cloacal temperature, as observed by Ost and Peixoto (2000). CP levels did not interfere on cloacal temperatures during the hot period of the day (afternoon); however, when at thermal comfort temperatures (morning), hens fed 15\% CP presented lower body temperature than those fed $18 \%$ CP. An explanation for this increase in temperature may be the high heat increment of protein. During the afternoon, the average environmental temperature of $30.6^{\circ} \mathrm{C}$ may have reduced feed intake, and consequently, protein intake.

Table 6 - Effect of dietary metabolizable energy and crude protein levels on the cloacal temperature in the morning and in the afternoon of commercial layers reared in hot climate.

\begin{tabular}{lc}
\hline Factors & Cloacal temperature $\left({ }^{\circ} \mathrm{C}\right)$ \\
\hline Metabolizable energy $(\mathrm{kcal} / \mathrm{kg})$ & 41.16 \\
2700 & 41.11 \\
3100 & \\
\hline Crude protein (\%) & 41.12 \\
15 & 41.15 \\
\hline 18 & \\
\hline Period of the day & $41.02 \mathrm{a}$ \\
Morning $\left(21.8^{\circ} \mathrm{C}\right)$ & $41.26 \mathrm{~b}$ \\
\hline Afternoon $\left(31.4^{\circ} \mathrm{C}\right)$ & \\
\hline Analysis of variance & 0.0952 \\
Metabolizable energy (ME) & 0.2817 \\
Crude protein (CP) & $<0.0001$ \\
Period of the day (PD) & 0.3620 \\
ME x CP interaction & 0.8176 \\
ME x PD interaction & 0.0619 \\
$C P \times P D$ interaction & 0.9572 \\
\hline ME x CP x PD interaction & 0.40 \\
\hline $\mathrm{CV}(\%)$ & \\
\hline Means followed by different letters in the same column, within each \\
factor, are different by the F test (95\%).
\end{tabular}

Table 7 - Effect of the interaction between period of the day and dietary crude protein level on cloacal temperature $\left({ }^{\circ} \mathrm{C}\right)$ of commercial layers reared in hot climate.

\begin{tabular}{lcc}
\hline \multirow{2}{*}{ Period of the day } & \multicolumn{3}{c}{ Crude protein (\%) } \\
& $\mathbf{1 5}$ & $\mathbf{1 8}$ \\
\hline Morning $\left(21.8^{\circ} \mathrm{C}\right)$ & $40.97 \mathrm{bB}$ & $41.06 \mathrm{ab}$ \\
Afternoon $\left(31.4^{\circ} \mathrm{C}\right)$ & $41.25 \mathrm{Aa}$ & $41.27 \mathrm{aA}$ \\
\hline
\end{tabular}

Means followed by different small letters in the same row or capital letter in the same column are different by the F test (95\%).

\section{CONCLUSION}

It was concluded that dietary $\mathrm{CP}$ and ME levels influenced the performance and the body temperature of commercial layers.

\section{REFERENCES}

Andreotti MO, Junqueira OM, Barbosa MJ, Cancherini LC, Araújo LF Rodrigues EA. tempo de trânsito intestinal, desempenho, característica de carcaça e composição corporal de frangos de corte alimentados com rações isoenergéticas formuladas com diferentes níveis de óleo de soja. Revista Brasileira de Zootecnia 2004;33:870-879.

Bertechini AG. Nutrição de monogástricos. Lavras:Ediufla; 2006. p. 302.

Costa FGP, Quirino BJS, Givisiez PEN, Silva JHV, Almeida HHS, Costa JS, Oliveira CFS, Goulart CC. Poedeiras alimentadas com diferentes níveis de energia e óleo de soja na ração. Revista Archivos de Zootecnia 2009; 58:405-411.

Faria Filho de. Aspectos produtivos, metabólicos, econômicos e ambientais da nutrição protéica para frangos expostos ao calor [dissertação]. Jaboticabal (SP): Universidade Estadual Paulista; 2006.

Furlan RL, Macari M. Termorregulação. In: Macari M, Furlan RL, Gonzales E. Fisiologia aviária: aplicada a frangos de corte. 2 ed. Jaboticabal: Funep; 2002. p. 209-230.

Geraert PA, Padilha JCF, Guillaumin S. Metabolic and endocrine changes induced by chronic heat exposure in broiler chickens: growth performance, body composition and energy retention. British Journal of Nutrition 1996;75:195-204.

Harms RH, Russell GB, Sloan DR. Performance of four strains of commercial layers with major changes in dietary energy. Journal of Applied Poultry Science 2000;54:536-551.

Koh K, Macleod MG. Effects of ambient temperature on heat increment of feeding and energy retention in growing broilers maintained at different food intakes. British Poultry Science 1999;40:511-516.

Littell RC, Stroup WW, Freund RJ. SAS For Linear Models. $4^{\text {th }}$ ed. Cary: SAS Institute; 2002

Leeson S, Summers JD, Diaz GJ. Nutrición Aviar Comercial. Santafé de Bogotá, Colombia; 2000. p. 359.

Mateos GG, Sell JL. Influence of fat and carbohydrate source on rate of food passage of semipurified diets for laying hens. Poultry Science 1981;60:2114-2119.

Mateos GG, Sell JL, Eastwood AJ. Rate of food passage (time transit) as influenced by level of supplemental fat. Poultry Science 1982;61:94100.

Moraes VMB, Macari M, Kronka SN. Preferência alimentar de poedeiras comerciais de rações contendo diferentes densidades energéticas. Pesquisa Agropecuária Brasileira 1991; 26:1809-1813.

Nesheim MC, Austic RE, Card LE. Poultry production. $12^{\text {th }}$ ed. Philadelphia: Lea; Febiger; 1979.

Ost RP, Peixoto RR. Níveis de energia metabolizável em rações para poedeiras de ovos marrons nas condições de inverno e verão da região de Pelotas- RS. Revista Brasileira de Zootecnia 2000; 29(6):2283-2291.

Pavan AC, Móri C, Garcia EA, Scherer MR, Pizzolante CC. Níveis de proteína bruta e de aminoácidos sulfurados totais sobre o desempenho, a 
Almeida VR, Dias AN, Bueno CFD,

Couto FAP, Rodrigues PA, Nogueira WCL, Faria Filho DE

qualidade dos ovos e a excreção de nitrogênio de poedeiras de ovos marrons. Revista Brasileira de Zootecnia 2005;34(2):568-574.

Pinto R, Ferreira AS, Albino LFT. Níveis de proteína e energia para codornas japonesas em postura. Revista Brasileira de Zootecnia 2002; 31(4):1761-1770.

Pond WG, Church DC, Pond KR. Basic animal nutrition and feeding. $5^{\text {th }}$ ed. New York: John Wiley \& Sons; 2005. p. 580.

Rabello CBV, Pinto AL, Silva EP, Lima SBP. Níveis de óleo de soja na dieta de poedeiras comerciais criadas em região de alta temperatura. Revista Brasileira de Ciências Agrárias 2007;2(2):174-182.

Rosa AP, Zanella I, Vieira NS. Efeito de diferentes níveis de proteína e energia no desempenho de fêmeas Plymouth Rock Barrada na fase de postura. Ciência Rural 1996; 26(2):289-296.

Rostagno HS, Albino LFT, Donzele JL, Gomes PC, Oliveira RF, Lopes DC, Ferreira AS, Barreto SLT. Tabelas brasileiras para aves e suínos: Composição de alimentos e exigências nutricionais. 2 ed. Viçosa: Universiade Federal de Viçosa; 2005. p. 186.

Sakomura NK, Basaglia R, Safortes CML, Fernandes JBK. Modelos para estimar as exigências de energia metabolizável para poedeiras. Revista Brasileira de Zootecnia 2005; 34(2):575-583.

Usayran N, Farran MT, Awadallah HH. Effects of added dietary fat and phosphorus on the performance and egg quality of laying hens subjected to a constant high environmental temperature. Poultry Science 2001;80(12):1695-1701. 